\title{
Winter and Summer Structure of the Caribbean Low-Level Jet
}

\author{
ERnesto Muñoz and Antonio J. Busalacchi \\ Earth System Science Interdisciplinary Center, and Department of Atmospheric and Oceanic Science, University of Maryland, \\ College Park, College Park, Maryland \\ SUMANT NigAM \\ Department of Atmospheric and Oceanic Science, and Earth System Science Interdisciplinary Center, University of Maryland, \\ College Park, College Park, Maryland \\ Alfredo Ruiz-BARRAdas \\ Department of Atmospheric and Oceanic Science, University of Maryland, College Park, College Park, Maryland
}

(Manuscript received 22 January 2007, in final form 13 July 2007)

\begin{abstract}
The Caribbean region shows maxima in easterly winds greater than $12 \mathrm{~m} \mathrm{~s}^{-1}$ at $925 \mathrm{hPa}$ in July and February, herein referred to as the summer and winter Caribbean low-level jet (LLJ), respectively. It is important to understand the controls and influences of the Caribbean LLJ because other LLJs have been observed to be related to precipitation variability. The purpose of this study is to identify the mechanisms of the Caribbean LLJ formation and variability and their association to the regional hydroclimate. Climatological fields are calculated from the North American Regional Reanalysis and the 40-yr ECMWF Re-Analysis from 1979 to 2001 . It is observed that the low-level (925 hPa) zonal wind over the Caribbean basin has a semiannual cycle and an interannual variability, with greater standard deviation during boreal summer. The semiannual cycle has peaks in February and July, which are regional amplifications of the large-scale circulation. High mountains to the south of the Caribbean Sea influence the air temperature meridional gradient, providing a baroclinic structure that favors a stronger easterly wind. The boreal summer strengthening of the Caribbean LLJ is associated with subsidence over the subtropical North Atlantic from the May-to-July shift of the ITCZ and the evolution of the Central American monsoon. Additionally, the midsummer minimum of Caribbean precipitation is related to the Caribbean LLJ through greater moisture flux divergence. From May to September the moisture carried by the Caribbean LLJ into the Gulf of Mexico is strongest. The summer interannual variability of the Caribbean LLJ is due to the variability of the meridional pressure gradient across the Caribbean basin, influenced by tropical Pacific variability during summer.
\end{abstract}

\section{Introduction}

Low-level jets (LLJs) are regional maxima of winds in the lower troposphere (Stensrud 1996). Two prominent LLJs in the Americas are the Great Plains LLJ (GPLLJ; Helfand and Schubert 1995; Ting and Wang 2006) and the South American LLJ (SALLJ; Berbery and Collini 2000; Vera et al. 2006). Whereas a body of

Corresponding author address: Ernesto Muñoz, Cooperative Institute for Marine and Atmospheric Studies, University of Miami, 4600 Rickenbacker Causeway, Miami, FL 33149.

E-mail: ernesto.munoz@noaa.gov research has developed over the past decade regarding the GPLLJ and the SALLJ, the easterly LLJ over the Caribbean Sea has remained understudied. With a peak during summer, the Caribbean LLJ is part of the circulation that flows from the Caribbean Sea through the Gulf of Mexico, transporting moisture into the continental United States (Rasmusson 1967; Bosilovich and Schubert 2002). A greater understanding of the Caribbean LLJ will improve our understanding of the role of the Caribbean atmospheric circulation on the atmospheric moisture fluxes from the Caribbean Sea.

Currently, only a few studies explicitly document the atmospheric low-level jet in the Caribbean and 
some aspects of its annual and interannual variability. Stensrud (1996) indicated the western Caribbean Sea to be an area where a low-level atmospheric jet is suspected to exist. More recently, Mo et al. (2005) identified a summer maximum of surface (scatterometer) zonal winds over the region $\left(12^{\circ}-14^{\circ} \mathrm{N}, 70^{\circ}-80^{\circ} \mathrm{W}\right)$, and associated it with the Caribbean LLJ. Still, much is unknown about the forcings of the Caribbean LLJ (either local or remote) or about the influences the LLJ has on the regional hydroclimate. This study will focus on the seasonal and interannual variability of the easterly LLJ over the Caribbean Sea and its forcings from the regional- and larger-scale climate.

Although no single definition applies to all LLJs in the global atmosphere, there are a few characteristics that serve to identify an atmospheric LLJ as discussed by Stensrud (1996). The principal criterion is the existence of a maximum in wind speed in a contained area in the lower levels (below $700 \mathrm{hPa}$ ) of the atmosphere, that is, a narrow band of strong winds. The vertical structure of the wind should be one with vertical shear, that is, a wind vertical profile with weaker winds at the bottom, a maximum in wind speed above, and a decrease of wind speed at higher levels. Another criterion is a horizontal wind structure with horizontal shear, that is, weaker winds at the edges of the jet. These criteria are met by the LLJ in the Caribbean, as demonstrated in this study.

A similarity between the Caribbean LLJ and the GPLLJ and SALLJ is that they flow along mountains. The GPLLJ flows along the eastern side of the Sierra Madre and the Rocky Mountains of North America while the SALLJ flows along the eastern side of the Andes of South America. The Caribbean Sea, over which the Caribbean LLJ flows, is bounded to the south by the northern coast of South America, which has mountains higher than $1 \mathrm{~km}$. The GPLLJ and the SALLJ have been observed to be influenced by the horizontal temperature gradients resulting from the topography of their domain (Holton 1967). The potential of a similar influence from the mountains of northern South America on the Caribbean LLJ is presented in this study.

Other LLJs, such as the Great Plains and the South American LLJs, have been shown to be important for their potential to transport moisture from remote upwind regions, their relation to nighttime convection, and their potential to alter the convergent and divergent circulations on interannual time scales (Blackadar 1957; Bonner and Paegle 1970; Berbery and Barros 2002). LLJs have an important role in the exchange of atmospheric water vapor from upwind to downwind re- gions (Berbery et al. 1996). Previous studies (Rasmusson 1967; Bosilovich and Schubert 2002) have indicated the Caribbean Sea as a moisture source for the Gulf of Mexico and the continental United States during boreal summer. In this study the moisture fluxes are quantified over the Caribbean Sea from the North American Regional Reanalysis (NARR).

The annual cycle of precipitation in the Caribbean and Central American region has a rainy season in boreal summer (Giannini et al. 2000; Taylor et al. 2002) that extends from May through October. During boreal summer the intertropical convergence zone (ITCZ) shifts northward, leading to intense precipitation over the tropical North Atlantic, Central America, and the tropical northeastern Pacific. However, over the Caribbean Sea the precipitation is not as intense as it is over Central America. Also, the Caribbean and Central American summer rainy season is bisected by a relative minimum in July-August, the canícula or midsummer drought (Magaña et al. 1999), and a semiannual cycle of cyclogenesis (Inoue et al. 2002). The relation of the Caribbean LLJ with the regional hydroclimate is discussed in this study.

A purpose of this study is, therefore, to identify the mechanisms of the Caribbean LLJ formation from climatological fields. Also, we aim to identify the Caribbean LLJ's relation to the regional- and large-scale climate during boreal summer. Specific questions we would like to address are the following: What regional conditions determine the vertical and horizontal structure of the Caribbean LLJ during its peaks? What large-scale conditions determine the seasonal variability of the Caribbean LLJ? How is the Caribbean LLJ related to the moisture fluxes and precipitation over the Caribbean Sea? To what is the summer interannual variability of the Caribbean LLJ related?

The presentation of this study is as follows. In the following section we indicate the data used for the study. Then, a discussion of the seasonal and diurnal cycles of the Caribbean zonal winds is presented. This is followed by a characterization of the horizontal and vertical structures of the Caribbean LLJ. The Caribbean LLJ is further discussed in light of the moisture flux structure and seasonal cycle. The basic features of the Caribbean easterly wind relative to the regional mechanisms and the factors at play during boreal summer are addressed by discussing the larger-scale seasonal changes that induce the onset of the summer Caribbean LLJ, the Caribbean summer minimum in precipitation, and the summer interannual variability of the Caribbean LLJ. 


\section{Data and approach}

The primary sources of atmospheric data used in this study are the NARR (Mesinger et al. 2006) and the 40-yr European Centre for Medium-Range Weather Forecasts (ECMWF) Re-Analysis (ERA-40; Uppala et al. 2005). The NARR has an advantage over other reanalyses in that, in addition to assimilating the usual type of observations, it assimilates precipitation. Other positive attributes of the NARR are the high horizontal resolution $(32 \mathrm{~km} \times 32 \mathrm{~km})$ and vertical resolution $(25$ hPa below $700 \mathrm{hPa}$ ), and a temporal resolution of $3 \mathrm{~h}$. However, as implied by its name, the NARR only covers the North American continent with $7^{\circ} \mathrm{N}$ as its southernmost boundary. So, even though the NARR covers the Caribbean Sea region, it does not cover a large part of the nearby tropical Atlantic and Pacific basins. The ERA-40 global reanalysis is then used to analyze the large-scale climate connections. Also, the National Centers for Environmental Prediction-National Center for Atmospheric Research (NCEP-NCAR) reanalysis (Kalnay et al. 1996) irrotational and rotational components of the 925- and 250-hPa wind are analyzed.

Precipitation and sea surface temperature (SST) data are also analyzed. The Global Precipitation Climatology Project (GPCP; Adler et al. 2003) provides monthly precipitation with $2.5^{\circ} \times 2.5^{\circ}$ spatial resolution, covering the period since 1979 with a greater spatial coverage than the NARR. To analyze water temperature, we rely on the National Oceanic and Atmospheric Administration (NOAA) Optimum Interpolation SST (OISST) $1^{\circ} \times 1^{\circ}$ dataset (Reynolds et al. 2002) for the climatology from 1982 to 2001. For regression analyses of SST from 1979 to 2001, we used the NOAA Extended Reconstructed SST $2^{\circ} \times 2^{\circ}$ dataset (Smith and Reynolds 2004). From the previously listed data we have quantified the monthly climatology from 1979 to 2001 (except for OISST). For the interannual variability component we quantified the monthly anomalies for the same base period (1979-2001).

As presented below, over the Caribbean Sea the meridional component of the wind is very small compared to the zonal component of the wind. Because of this, the focus of this Caribbean LLJ study is on the zonal component of the wind. The approach was based on the use of climatological maps of assorted variables. The focus was on the months when the Caribbean LLJ is at its peak, in February and July. A comparison between the Caribbean LLJ summer peak in July and the winter peak in February is presented. Also compared are the moisture fluxes associated with the Caribbean LLJ. We analyze the summer intensification of the Caribbean LLJ by calculating the difference of the May and June monthly climatologies. The climatological analysis of the hydroclimate is based on factors related to the June-July spatial and temporal minimum of precipitation in the Caribbean. The interannual variability is analyzed by linear regression of sea level pressure and sea surface temperature to an anomaly index of the Caribbean LLJ.

\section{The Caribbean low-level jet}

\section{a. Seasonal and diurnal variability}

The Caribbean wind is predominantly zonal with an easterly direction year-round. Figure 1 presents the 925-hPa wind vector and speed for February and July (which are the level and months of the maximum wind intensity). The region of the maximum easterly winds is the central Caribbean Sea between $12^{\circ}-16^{\circ} \mathrm{N}$ and $71^{\circ}-76^{\circ} \mathrm{W}$. Figure 2 presents the vertical profile of the zonal wind averaged in the indicated region of maximum winds. Over the Caribbean Sea the maximum zonal winds are at about $925 \mathrm{hPa}$ (Fig. 2) in both the NARR and the ERA-40. At this level, the zonal Caribbean winds fluctuate in strength throughout the year, being stronger in July and February and weaker in October and May, which is indicative of a semiannual cycle (Fig. 2).

The July peak of the Caribbean LLJ is the main peak, with winds greater than $13 \mathrm{~m} \mathrm{~s}^{-1}$. In the NARR the July peak is stronger than the February peak by $\sim 1 \mathrm{~m} \mathrm{~s}^{-1}$, while in ERA-40 the July peak is stronger than the February peak by $\sim 2 \mathrm{~m} \mathrm{~s}^{-1}$. The main minimum is in October, with winds as low as $8.5 \mathrm{~m} \mathrm{~s}^{-1}$. The Caribbean zonal winds from the NARR and the ERA40 have a similar cycle throughout the year (Fig. 2). However, the Caribbean zonal winds of ERA-40 are stronger than the Caribbean zonal winds of NARR throughout the calendar months. Albeit the differences, both reanalyses show the Caribbean LLJ structure. The LLJ structure will be discussed in the following section, relying mostly on NARR, which has a higher resolution (than ERA-40) in the horizontal and vertical dimensions and in time.

The variability of the 925-hPa zonal wind throughout the day is characterized by a semidiurnal cycle in July and February. Figure 3 presents the July and February 3-hourly climatology of the zonal wind at $13^{\circ} \mathrm{N}$ and $74^{\circ} \mathrm{W}$, a location of maximum winds in both July and February. At this location the maximum easterly winds in the vertical are at the 925-hPa level. In the months of July and February, the $925-\mathrm{hPa}$ easterly wind peaks at 0300 (2300 LT) and 1200 (0800 LT) UTC, with average winds of $15.1 \mathrm{~m} \mathrm{~s}^{-1}$ in July and $14.4 \mathrm{~m} \mathrm{~s}^{-1}$ in February. 

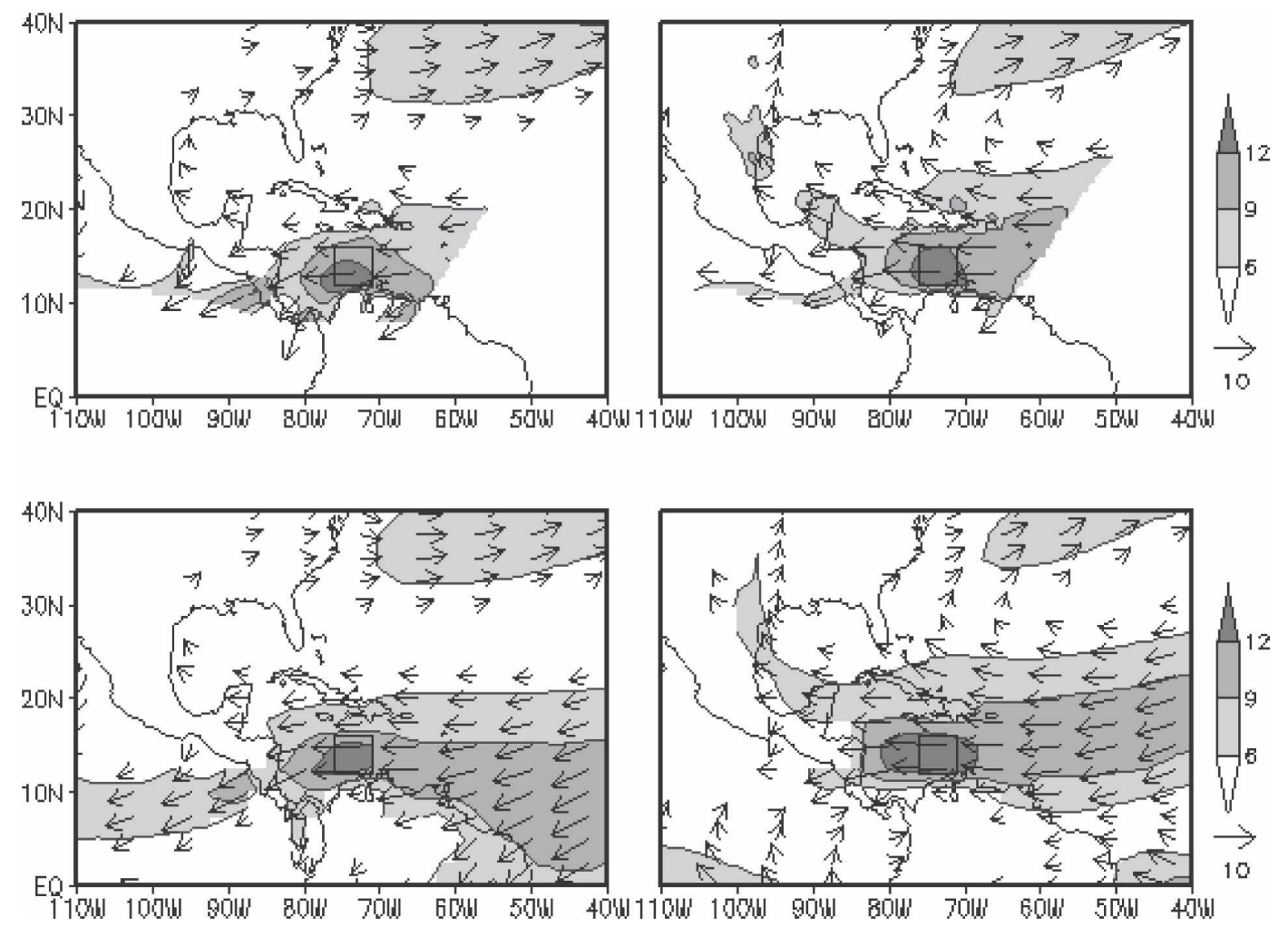

FIG. 1. (left) February and (right) July climatology of 925 -hPa winds from the (top) NARR and (bottom) ERA-40. The base period is from 1979 to 2001 . The reference arrow is $10 \mathrm{~m} \mathrm{~s}^{-1}$. The shadings correspond to the magnitude of the vectors $\left(\mathrm{m} \mathrm{s}^{-1}\right)$. Vectors with speed less than $3 \mathrm{~m} \mathrm{~s}^{-1}$ are not shown. The limits of the NARR domain can be seen in the bottom-left and bottom-right corners of the plots. The rectangle delineates the area of the maximum wind speed from $12^{\circ}$ to $16^{\circ} \mathrm{N}$ and from $71^{\circ}$ to $76^{\circ} \mathrm{W}$.

These two maxima (at 0300 and 1200 UTC) are divided by a relative minimum that extends from $0600(0200$ LT) to 0900 (0500 LT) UTC. The absolute minimum is at 2100 UTC (1700 LT), with an easterly wind of 12.5 $\mathrm{m} \mathrm{s}^{-1}$ in July and in February. From the afternoon minimum at 2100 UTC (1700 LT) to the midnight maximum at 0300 UTC (2300 LT), the easterly wind strengthens $2.7 \mathrm{~m} \mathrm{~s}^{-1}$ in July and $1.5 \mathrm{~m} \mathrm{~s}^{-1}$ in February. From the morning maximum at 1200 UTC (0800 LT) to the afternoon minimum at 2100 UTC (1700 LT), the easterly wind weakens $2.5 \mathrm{~m} \mathrm{~s}^{-1}$ in July and $1.7 \mathrm{~m} \mathrm{~s}^{-1}$ in February. In both months, the 0300 UTC (2300 LT) maximum is $\sim 1.2$ times the 2100 UTC (1700 LT) minimum. The variability throughout the day, as given by the standard deviation of the $925-\mathrm{hPa}$ zonal wind, is 0.9 $\mathrm{m} \mathrm{s}^{-1}$ in July and $0.6 \mathrm{~m} \mathrm{~s}^{-1}$ in February, and represents a semidiurnal variability.

\section{b. Horizontal and vertical structure}

In July and February, the Caribbean LLJ is a regional amplification of the tropical North Atlantic easterly winds. These easterlies are associated with an anticyclone (the Bermuda high) over the subtropical North Atlantic (Fig. 4). After flowing over the Lesser Antilles (at about $61^{\circ} \mathrm{W}$ ) the tropical North Atlantic easterlies strengthen, becoming strongest over the central Caribbean Sea between $71^{\circ}$ and $76^{\circ} \mathrm{W}$ and between $12^{\circ}$ and $16^{\circ} \mathrm{N}$ (Fig. 1). In general, the central Caribbean maximum of easterly winds is bounded to the south by the mountains of northern South America and to the north by the Greater Antilles (at about $19^{\circ} \mathrm{N}$ ). The Caribbean Sea is like a valley bounded to the north and south by mountains higher than $1 \mathrm{~km}$ (Fig. 5). In both the NARR and ERA-40 the wind speed reaches values greater than $12 \mathrm{~m} \mathrm{~s}^{-1}$ in July and February between $13^{\circ}$ and $15^{\circ} \mathrm{N}$ (Fig. 1). The principal contributor to the wind speed in this region is the zonal component of the wind. There are weaker winds over the northernmost and southernmost Caribbean regions, forming a horizontal jet structure with horizontal shear.

Once the Caribbean LLJ reaches the western region of the Caribbean Sea, the easterly flow bifurcates (divides into two branches) to the northwest (a southeast- 

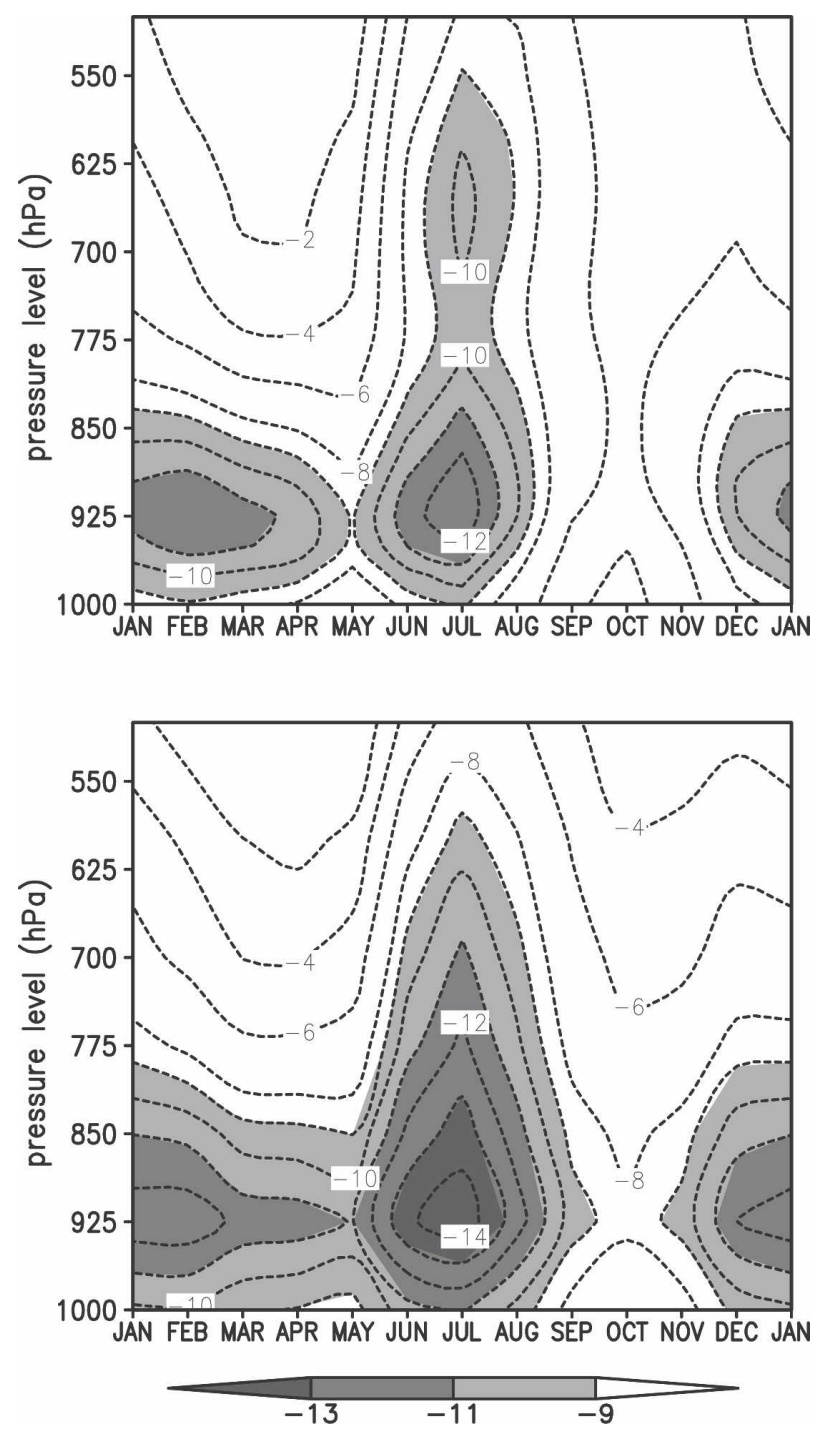

FIG. 2. Vertical profile of the zonal wind $\left(\mathrm{m} \mathrm{s}^{-1}\right)$, averaged for the column $71^{\circ}-76^{\circ} \mathrm{W}$ and $12^{\circ}-16^{\circ} \mathrm{N}$ from the (top) NARR and (bottom) ERA-40 for the calendar months. Negative indicates easterly.

erly branch) and southwest (a northeasterly branch). At the western boundary of the Caribbean Sea the easterlies encounter the mountains of Central America and the speed decreases, except through the valleys of Lake Nicaragua $\left(12^{\circ} \mathrm{N}, 85^{\circ} \mathrm{W}\right)$ and Panama $\left(8^{\circ} \mathrm{N}, 80^{\circ} \mathrm{W}\right)$. As observed from Fig. 1, the northeasterly branch of the bifurcation is stronger in February than in July and extends to the northeastern tropical Pacific as the Papagayo jet and the Panama jet (Xie et al. 2005). The southeasterly branch of the bifurcation flows over the Yucatan Cannel and over the Yucatan Peninsula into the Gulf of Mexico (Fig. 1). This southeasterly branch is stronger in July than in February. The southeasterly

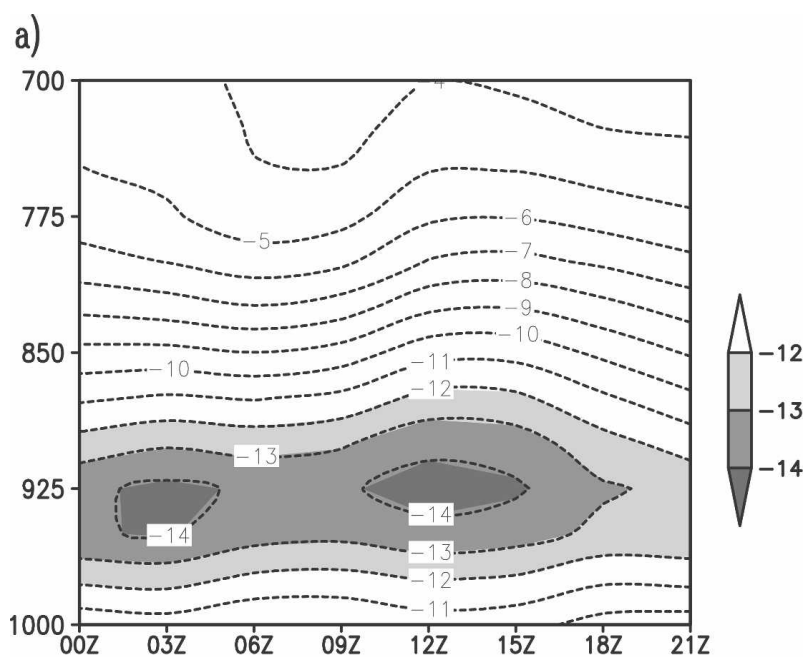

b)

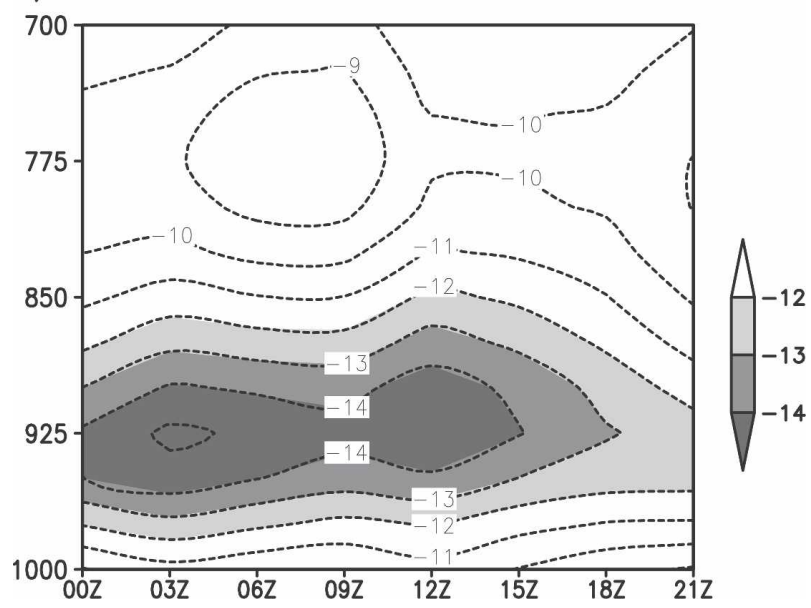

FIG. 3. Pressure-time plot of the (a) February and (b) July diurnal cycle of the zonal wind $\left(\mathrm{m} \mathrm{s}^{-1}\right)$ at $13^{\circ} \mathrm{N}$ and $74^{\circ} \mathrm{W}$ from the NARR.

branch joins the southerly flow into the Gulf States of the United States and the Great Plains low-level jet.

The vertical structure of the July and February Caribbean zonal winds with vertical shear throughout the lower levels resembles the structure of an LLJ. Figures $5 a, b$ show the pressure-latitude cross section of the zonal wind averaged from $71^{\circ}$ to $76^{\circ} \mathrm{W}$ in July and February from the NARR. In the vertical, the July and February Caribbean easterlies are maximum at the 925hPa level and weaker below and above that level. In NARR the maximum is concentrated at $13^{\circ} \mathrm{N}$, closer to the mountains of northern South America. There are weaker winds to the north and south of the $13^{\circ} \mathrm{N}$ maximum, with a difference of $6 \mathrm{~m} \mathrm{~s}^{-1}$. This vertical structure with vertical and horizontal wind shear is akin to a low-level jet structure. 
a)

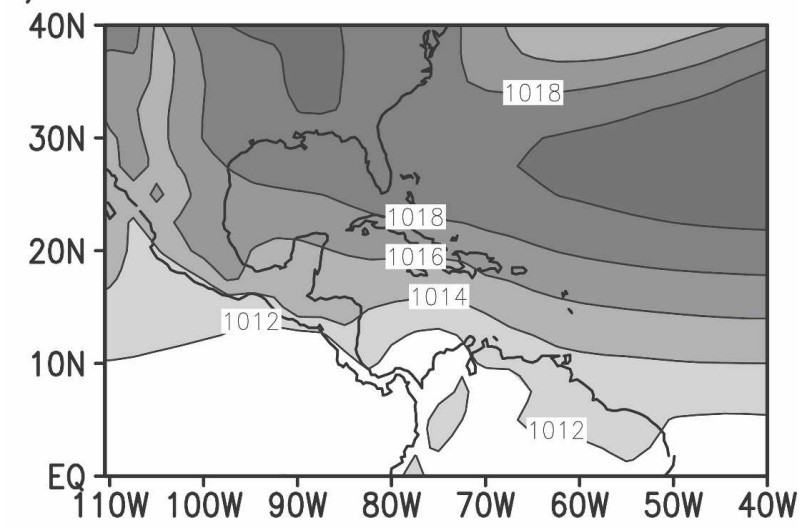

b)

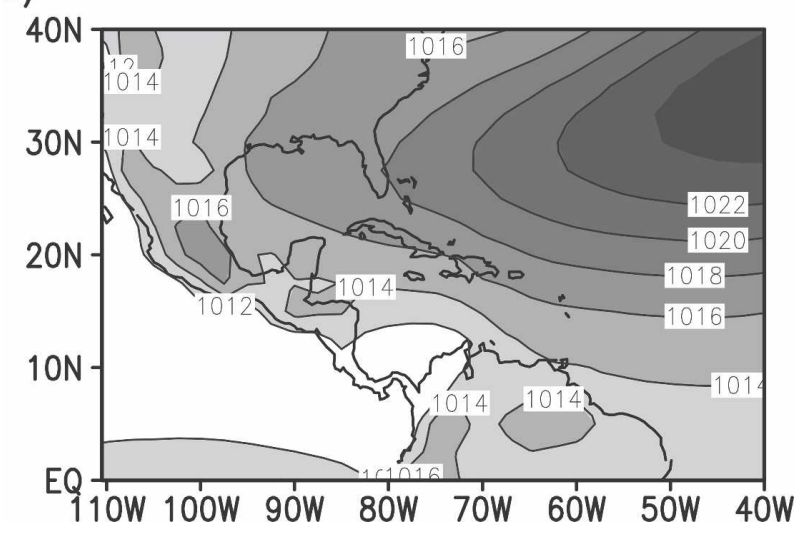

FIG. 4. (a) February and (b) July climatology of sea level pressure $(\mathrm{hPa})$ from ERA-40.

Over the Caribbean the geostrophic wind, calculated from the horizontal gradient of geopotential heights, compares well to the total wind between 700 and 950 $\mathrm{hPa}$ (figure not included). Over the central Caribbean $\left(14^{\circ}-16^{\circ} \mathrm{N}\right)$, between the $800-$ and the $925-\mathrm{hPa}$ levels, the geostrophic zonal wind is less than $5 \%$ different from the total zonal wind in July and February. However, below $975 \mathrm{hPa}$ the easterly total wind is weaker than the easterly geostrophic wind, and their difference is greater than $25 \%$ as the surface is approached. The difference below $950 \mathrm{hPa}$ is indicative of the frictional effects of the planetary boundary layer. The vertical effect of friction is manifest as a vertical profile with vertical shear, that is, weaker winds closer to the surface and stronger winds above $925 \mathrm{hPa}$.

The meridional gradients of temperature in the Caribbean indicate a baroclinic structure close to the mountains of northern South America. Figures 5c,d present the pressure-latitude cross section of the temperature and the departure from the meridional $\left(11^{\circ}-\right.$ $19^{\circ} \mathrm{N}$ ) mean of temperature in February and July. In both months, throughout the vertical range of the mountains of northern South America, the temperature increases southward from the central Caribbean $\left(14^{\circ}\right.$ $15^{\circ} \mathrm{N}$ ) toward the mountains (Figs. $5 \mathrm{c}$,d). Figures $5 \mathrm{e}, \mathrm{f}$ present the zonal thermal wind averaged from $71^{\circ}$ to $76^{\circ} \mathrm{W}$. The zonal thermal wind, a measure of the vertical shear of the zonal geostrophic wind, was calculated from the temperature change in the meridional direction according to Eq. (3.32) of Holton (1992). It is observed that the thermal wind is positive and strongest in the southern part of the Caribbean Sea below the 775$\mathrm{hPa}$ level (Figs. 5e,f). Where the thermal wind is positive, the easterly geostrophic wind increases with pressure (i.e., the zonal geostrophic wind becomes more negative as the surface is approached). The southward gradient of temperature and the stronger thermal wind represent a baroclinic structure that is favorable for a stronger easterly wind over the southern part of the Caribbean. Hence, the influence of the warming of the highlands of northern South America on the southward temperature gradient represents a regional influence on the intensification of the Caribbean LLJ.

However, in the northern part of the Caribbean the influence of the highlands (the Greater Antilles) weakens the easterly winds below $800 \mathrm{hPa}$. In July (Figs. $5 \mathrm{~d}, \mathrm{f})$, the temperature close to the southern slope of the Greater Antilles is warmer than over the central Caribbean. In this case, the northward gradient of temperature counteracts the pressure gradient by weakening the easterly wind. This northward gradient of temperature over the northern part of the Caribbean is strongest in the summer months as the Greater Antilles and the Caribbean waters are warmed by the seasonal march of the sun (not presented). It may be this competing effect between the southward and the northward temperature gradients, induced by the mountains to the south and north, which provides the Caribbean LLJ with a slanted orientation in the vertical with a maximum over the southern Caribbean between 900 and 950 hPa (Fig. 5b).

\section{c. Caribbean moisture flux structure and seasonal cycle}

The zonal moisture flux across the central Caribbean (averaged from $71^{\circ}$ to $76^{\circ} \mathrm{W}$ ) is presented in Fig. 6 for February (Fig. 6a) and July (Fig. 6b). The zonal moisture flux is calculated by multiplying the zonal component of the wind by the specific humidity. The region of the maximum easterly moisture flux is lower in the atmosphere than the region of the maximum easterly winds because the specific humidity is larger at lower levels. Nonetheless, the zonal moisture flux also has a 

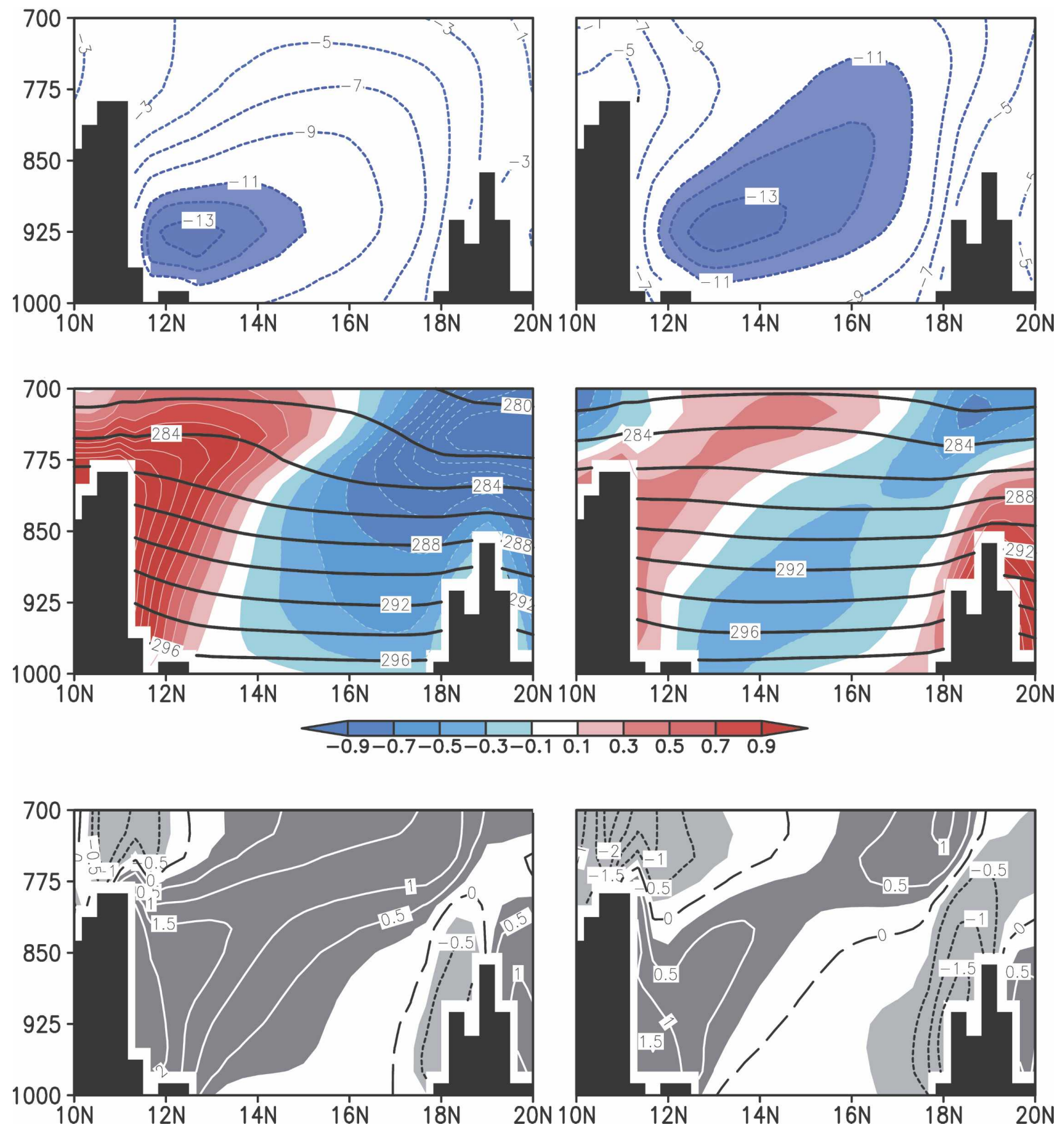

FIG. 5. Pressure-latitude cross section of the (left) February and (right) July zonal total wind, temperature, and thermal wind averaged from $71^{\circ}$ to $76^{\circ} \mathrm{W}$ from NARR. (top) Zonal component of the wind ( $\mathrm{m} \mathrm{s}^{-1}$ ); negative indicates easterly. (middle) Temperature ( $\mathrm{K}$, dark contours) and the departure from the meridional $\left(11^{\circ}-19^{\circ} \mathrm{N}\right)$ mean of temperature $(\mathrm{K}$, shadings). (bottom) Zonal thermal wind $\left(\mathrm{m} \mathrm{s}^{-1}\right)$; thermal wind values greater than 0.25 (solid contours) are shaded in dark gray, while values less than -0.25 (dashed contours) are shaded in light gray. The mountains of South America are observed at $11^{\circ} \mathrm{N}$ while the mountains of the Greater Antilles are observed at $19^{\circ} \mathrm{N}$.

jet-like structure, with greater easterly moisture flux centered at $13^{\circ} \mathrm{N}$ and weaker values to the south and to the north. The July easterly moisture flux has a maximum of $186 \mathrm{~g} \mathrm{~kg}^{-1} \mathrm{~m} \mathrm{~s}^{-1}$ centered at $13^{\circ} \mathrm{N}$ and $950 \mathrm{hPa}$.
In February the maximum of the easterly moisture flux is of $171 \mathrm{~g} \mathrm{~kg}^{-1} \mathrm{~m} \mathrm{~s}^{-1}$ centered at $12.6^{\circ} \mathrm{N}$ and $950 \mathrm{hPa}$. These maxima are close in magnitude and are closer to the mountains of northern South America in the south- 
a)

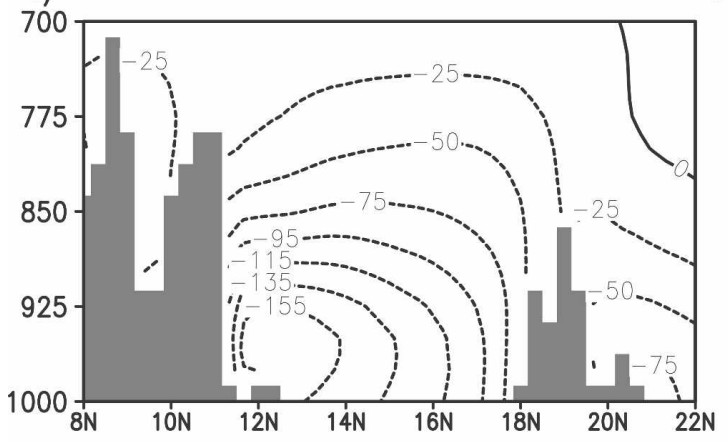

c)

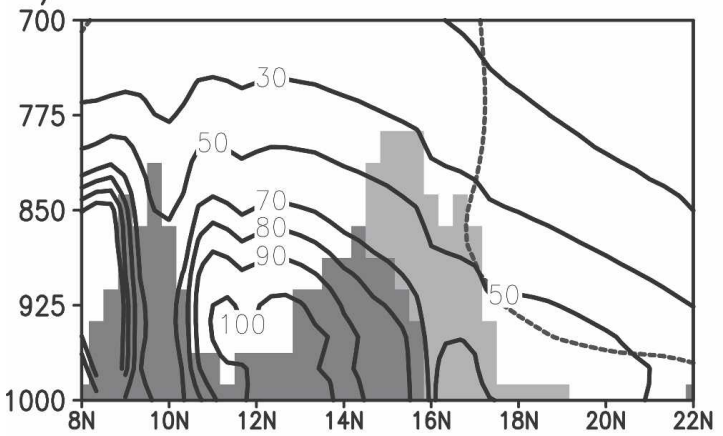

b)

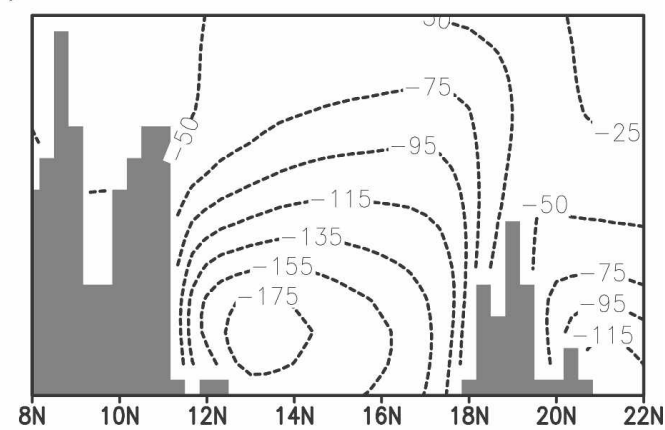

d)

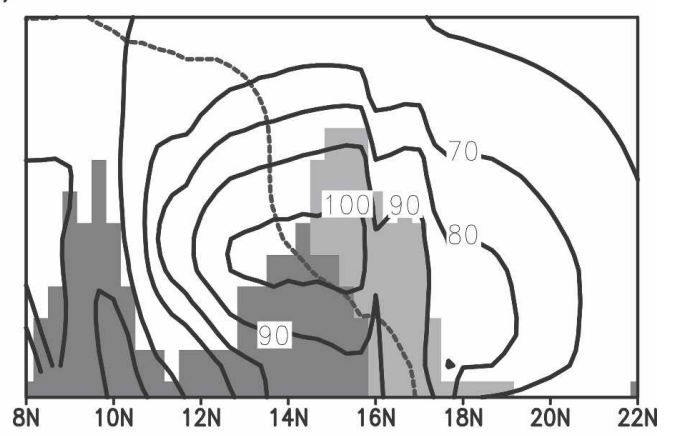

e)

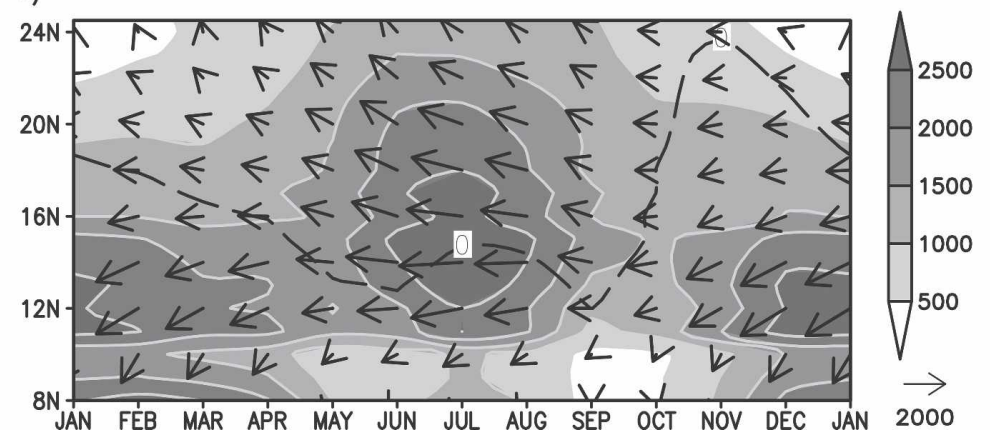

FIG. 6. Pressure-latitude cross sections and seasonal cycle of moisture flux from NARR. (top) Zonal moisture flux $\left(\mathrm{g} \mathrm{kg}^{-1} \mathrm{~m} \mathrm{~s}^{-1}\right.$ ) averaged from $71^{\circ}$ to $76^{\circ} \mathrm{W}$ for (a) February and (b) July. The mountains of northern South America and the Greater Antilles are shaded. (middle) Magnitude of the moisture flux vector $\left(\mathrm{g} \mathrm{kg}^{-1} \mathrm{~m} \mathrm{~s}^{-1}\right)$ averaged from $80^{\circ} \mathrm{W}$ to either the eastern side of the mountains of Central America or $93^{\circ} \mathrm{W}$ for (c) February and (d) July. The dashed line indicates where the meridional moisture flux is zero. The mountains of Central America are shaded in the background. Mountains shaded lighter are to the west of $88^{\circ} \mathrm{W}$. (bottom) Annual cycle of the moisture flux $\left(\mathrm{g} \mathrm{kg}^{-1} \mathrm{~m} \mathrm{~s}^{-1}\right.$ ) averaged from $80^{\circ} \mathrm{W}$ to either the eastern side of the mountains of Central America or $93^{\circ} \mathrm{W}$ and vertically integrated from 700 to $1000 \mathrm{hPa}$. The moisture flux vector is represented by arrows and the magnitude is shaded. The dashed line is the zero meridional moisture flux.

ern Caribbean. However, during July the easterly moisture flux below $850 \mathrm{hPa}$ and between $11^{\circ}$ and $19^{\circ} \mathrm{N}$ (i.e., between the mountains) is greater than in February. The difference in zonal moisture flux between February and July is due to both the greater specific humidity (not presented) and the stronger easterlies below 800 $\mathrm{hPa}$ in July than in February.

As indicated before, the flow over the western $\mathrm{Ca}$ - ribbean bifurcates into a southeasterly branch and a northeasterly branch. Figures $6 c$,d present the magnitude of the moisture flux vector averaged from $80^{\circ} \mathrm{W}$ to the eastern side of the mountains of Central America. The moisture fluxes west of where the terrain reaches the 975-hPa level were not included in this calculation of the zonal average from the NARR. Given this criterion, for example, the moisture fluxes over the Yucatan 
Peninsula were included because of the low-altitude terrain, but those over the highlands of Costa Rica and to the west were not included in the zonal average from $80^{\circ}$ to $93^{\circ} \mathrm{W}$. Figure $6 \mathrm{e}$ presents the seasonal cycle of the moisture flux vertically integrated from $700 \mathrm{hPa}$ to the surface. Throughout the year in the western Caribbean region the zonal direction of the moisture fluxes (and of the wind) is easterly, and the meridional direction is northerly over the southern part and southerly over the northern part. The split point (the bifurcation latitude) of the moisture flux in the western Caribbean is defined to be where the meridional moisture flux is zero (the dashed line in Figs. 6c-e) and is used to determine when and where the moisture fluxes from the central Caribbean contribute the most to the moisture budget of the Gulf of Mexico.

The annual cycle of the moisture fluxes over the western Caribbean is similar to the annual cycle of the central Caribbean LLJ, with peaks in winter and July and minima in May and October (Figs. 6e,7b). In July the southeasterly moisture flux into the Gulf of Mexico is twice as much as that in February (Figs. 6c-e). Also, the bifurcation of the flow over the western Caribbean lies more to the south in July than in February. This indicates a greater fetch of moisture from the Caribbean into the Gulf of Mexico in boreal summer. Below the 700-hPa level, about $2000 \mathrm{~g} \mathrm{~kg}^{-1} \mathrm{~m} \mathrm{~s}^{-1}$ flows northwestward in July (Fig. 6e) with greater amounts between 850 and $975 \mathrm{hPa}$ (Fig. 6d). The southeasterly and northeasterly branches have almost the same magnitude in July (Fig. 6d). In February most of the moisture flux over the western Caribbean is northeasterly, with about $2000 \mathrm{~g} \mathrm{~kg}^{-1} \mathrm{~m} \mathrm{~s}^{-1}$ (Fig. 6e) and a greater concentration below $900 \mathrm{hPa}$ (Fig. 6c). The winter peak of the Caribbean LLJ has a greater influence on the moisture fluxes on the southern half of Central America, while the summer peak of the Caribbean LLJ has a greater influence on the northern half of Central America and the Gulf of Mexico.

\section{Summer climate and the Caribbean LLJ}

The July and February peaks of the Caribbean LLJ are coincident with the strong northward gradients of SLP across the Caribbean Sea. The southwestern fringes of the Bermuda high [i.e., the subtropical North Atlantic (SNA) anticyclone] extend to the region of the Greater Antilles (Fig. 4). Figure 7 shows the SLP across the Caribbean region, averaged zonally from $71^{\circ}$ to $76^{\circ} \mathrm{W}$. Throughout the year, the pressure in the southern Caribbean is less than to the north (a northward pressure gradient). As observed from Fig. 7, over the southern Caribbean Sea, at $12^{\circ} \mathrm{N}$, the pressure does not

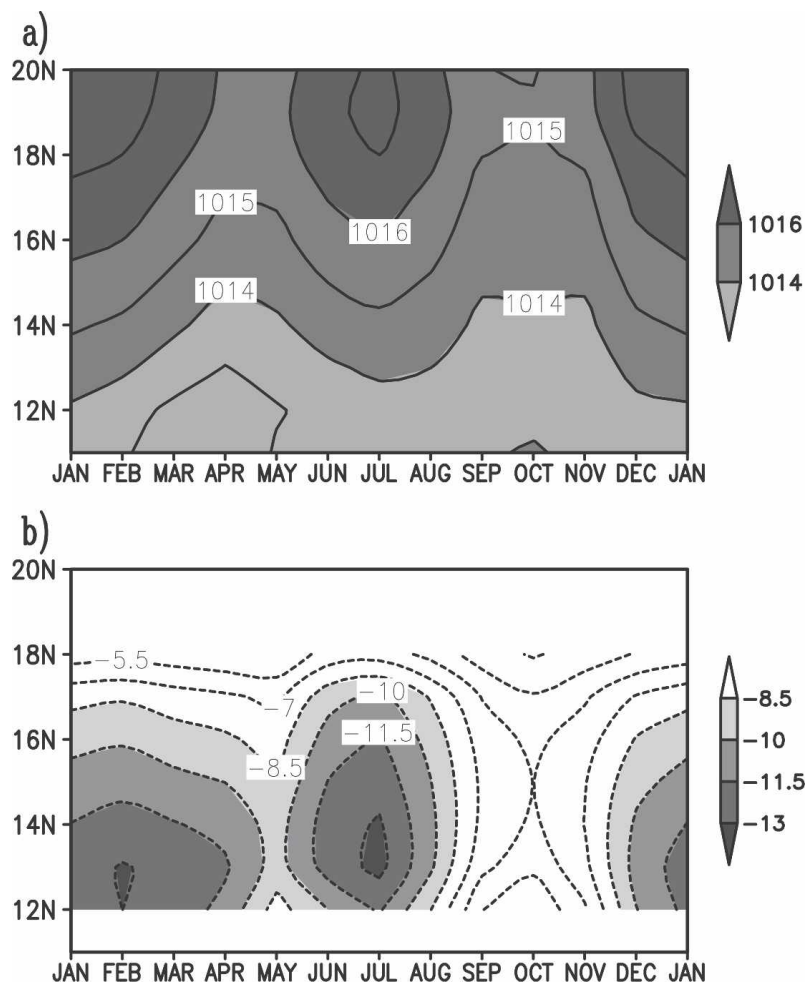

FIG. 7. Annual cycle of the $71^{\circ}-76^{\circ} \mathrm{W}$ zonal average of (a) sea level pressure (hPa, contour interval of $2 \mathrm{hPa}$ ) and (b) $925-\mathrm{hPa}$ zonal wind $\left(\mathrm{m} \mathrm{s}^{-1}\right.$, contour interval of $\left.1.5 \mathrm{~m} \mathrm{~s}^{-1}\right)$ from NARR. The Greater Antilles are at about $19^{\circ} \mathrm{N}$ and South America at $11^{\circ} \mathrm{N}$.

vary throughout the year as much as to the north, at $18^{\circ} \mathrm{N}$, where the $1016-\mathrm{hPa}$ isobar is seen to intrude in January and July and retract in May and October. During January and July (May and October) the anticyclone over the SNA has strengthened (weakened) and the SLP northward gradient across the Caribbean strengthens (weakens). The semiannual cycle of the northward SLP gradient is in phase with the semiannual cycle of the zonal wind across the Caribbean Sea.

The changes in SLP in boreal winter over the SNA are coherent with subsidence over the SNA from the Atlantic Hadley cell. During boreal winter there is a cross-equatorial overturning circulation with a rising motion over the southern subtropics and a sinking motion over the northern subtropics. This interhemispheric (Southern-Northern Hemisphere) Atlantic Hadley cell is related to the boreal winter (December-February) anticyclone over the SNA. On the other hand, the summer subtropical anticyclone over the SNA has been explained as a remote response to the Asian summer monsoon heating (Chen et al. 2001) and the monsoonal heating over North America (Rodwell 

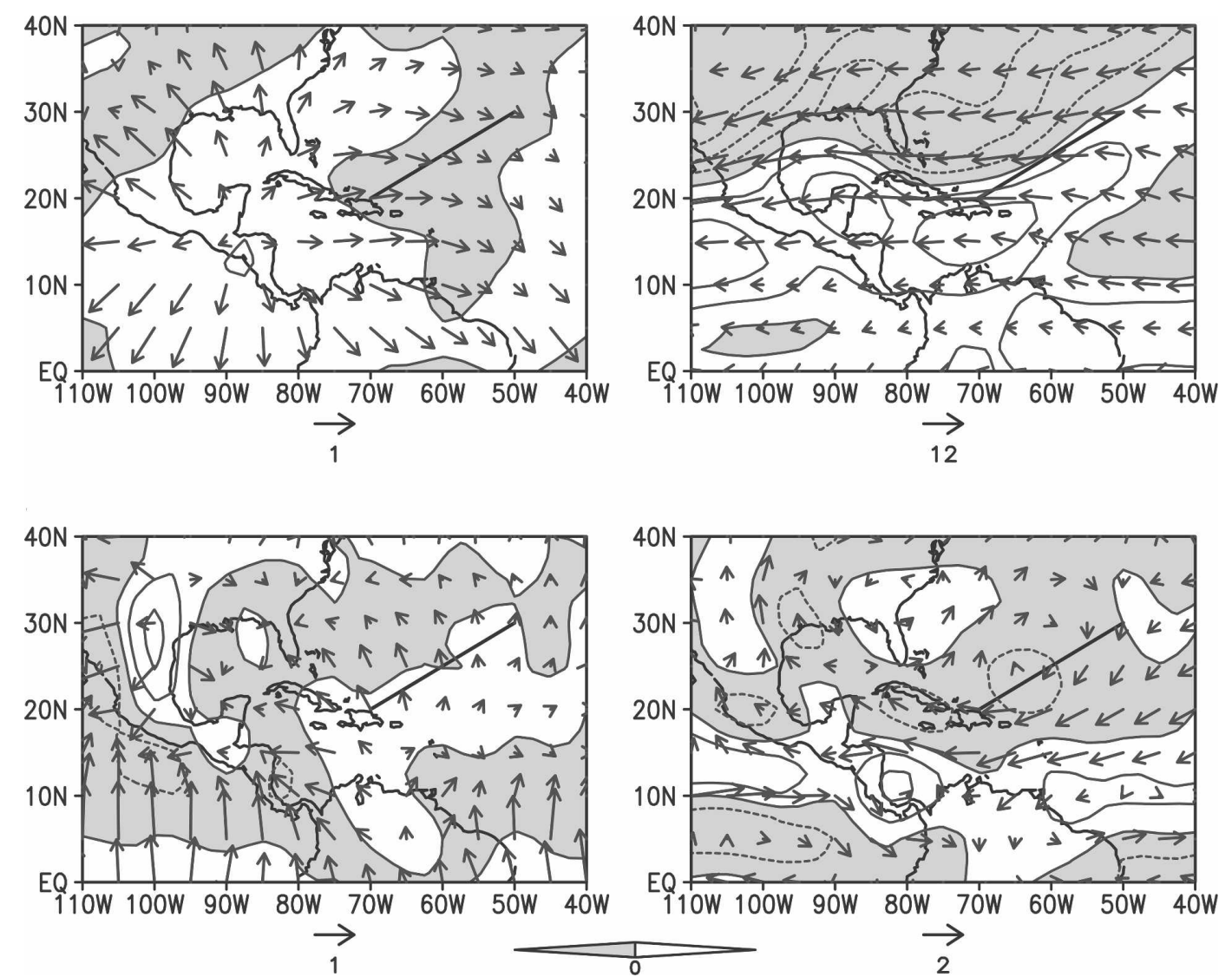

FIG. 8. June-May difference of (left) the irrotational wind and its divergence and (right) the rotational wind and its vorticity at (top) 250 and (bottom) $925 \mathrm{hPa}$ from the NCEP-NCAR reanalysis. Reference arrow in m s${ }^{-1}$. Negative values are shaded. A reference line has been drawn from $20^{\circ} \mathrm{N}, 70^{\circ} \mathrm{W}$ to $30^{\circ} \mathrm{N}, 50^{\circ} \mathrm{W}$. Contour interval for the difference in divergence is $2 \mathrm{~s}^{-1} \times 10^{-6}$, and for the difference in vorticity at $250 \mathrm{hPa}$ is $4 \mathrm{~s}^{-1} \times 10^{-6}$ and at $925 \mathrm{hPa}$ is $3 \mathrm{~s}^{-1} \times 10^{-6}$.

and Hoskins 2001), amplified by air-sea interactions (Seager et al. 2003). As Rodwell and Hoskins (2001) indicate, the effect of the Asian monsoon heating is amplified by the interaction with the midlatitude westerlies, producing adiabatic (and diabatically enhanced) descent and longwave cooling to the east (Rodwell and Hoskins 2001) of the anticyclone. To its west, monsoonal heating over land triggers a Kelvin wave response, forming the equatorward flank of the anticyclone (Rodwell and Hoskins 2001), and contributes to the zonal asymmetries of sea surface temperature (across the basin) that amplify the subtropical anticyclone (Seager et al. 2003).

\section{a. Summer strengthening of the Caribbean LLJ}

The Caribbean zonal winds strengthen by $\sim 3 \mathrm{~m} \mathrm{~s}^{-1}$ from May to June, representing the onset of the summer Caribbean LLJ. For further discussion of the intensification of the Caribbean easterly wind we show the changes from May to June of the rotational wind and its divergence, and the irrotational wind and its vorticity at 925 and $250 \mathrm{hPa}$ in Fig. 8. To facilitate the discussion a line from $20^{\circ} \mathrm{N}, 70^{\circ} \mathrm{W}$ to $30^{\circ} \mathrm{N}, 50^{\circ} \mathrm{W}$ serves as a guide for comparisons. As the Central American monsoon intensifies from May to June, the region of upper-level divergence shifts from the northeast of South America to Central America (Fig. 8a). The upper-level irrotational outflow from the Central American region connects to a region of upper-level convergence northeast of the Greater Antilles. The region northeast of the Greater Antilles also shows an increase of midtropospheric subsidence (not presented), lowerlevel divergence (Fig. 8c), and lower-level anticyclonic relative vorticity (Fig. 8d). In the tropical Atlantic at around $10^{\circ} \mathrm{N}$, cyclonic vorticity intensifies (Fig. 8d) [perhaps as a result of a Rossby wave response (Gill 1980) to the tropical Atlantic marine ITCZ warming]. These changes in lower-level vorticity to the north and south of the Caribbean basin lead to an intensification 
of the easterly rotational wind from the SNA into the Caribbean Sea. Also, to the southwest of the Caribbean (over Costa Rica and Panama) there is an increase of the cyclonic relative vorticity further intensifying the rotational easterly wind from the central Caribbean to the eastern coast of Central America (Fig. 8d). Additionally, having an increase in convergence to the west and an increase in divergence to the east, a stronger easterly irrotational wind over the western Caribbean is also part of the Caribbean LLJ intensification from May to June (Fig. 8c).

\section{b. Summer Caribbean minimum of precipitation}

During July the ITCZ is strongest over the tropical North Atlantic, Central America, and the tropical northeastern Pacific (Fig. 9). However, as observed in Fig. 9, the precipitation over the Caribbean Sea is not as intense as the precipitation over Central America. The spatial pattern of the precipitation rate for July shows a relative spatial minimum of precipitation centered over the Caribbean Sea. The precipitation increases from the central Caribbean Sea to the west, reaching values greater than $8 \mathrm{~mm} \mathrm{day}^{-1}$ west of Central America, corresponding to the ITCZ. The relative spatial minimum of precipitation over the Caribbean Sea coexists with SSTs greater than $27.5^{\circ} \mathrm{C}$ (Figs. 9a,c). SSTs greater than $27.5^{\circ} \mathrm{C}$ are considered over the threshold for convective precipitation in other tropical regions (Graham and Barnett 1987). However, for the Caribbean Sea, even though the SSTs are greater than $27.5^{\circ} \mathrm{C}$, the precipitation is a relative minimum with less than $2 \mathrm{~mm} \mathrm{day}^{-1}$. Other regions adjacent to the Caribbean Sea with relatively weak precipitation and SSTs greater than $28.5^{\circ} \mathrm{C}$ are the Gulf of Mexico and the region north of the Greater Antilles and south of $27^{\circ} \mathrm{N}$ (Figs. 9a,c).

These regions of weak precipitation, in particular the Caribbean Sea and the Gulf of Mexico, are collocated with regions of subsidence. Figure $9 \mathrm{~b}$ presents the vertical velocity at $850 \mathrm{hPa}$ from the ERA-40. There is descending motion over the Caribbean Sea, the Gulf of Mexico, and north of the Greater Antilles. Over the adjacent land areas, that is, Mexico, Central America, and South America, there is ascending motion; an exception is the western side of Central America at about $13^{\circ} \mathrm{N}$ where there is descending motion. The subsidence in the Gulf of Mexico is stronger at about $25^{\circ} \mathrm{N}$ below $700 \mathrm{hPa}$ and in the Caribbean is stronger between $66^{\circ}$ and $74^{\circ} \mathrm{W}$ below $500 \mathrm{hPa}$.

The regions of subsidence are also regions of moisture flux divergence (MFD) that are vertically integrated below $700 \mathrm{hPa}$ (from NARR). MFD extends throughout most of the Caribbean Sea, the Gulf of
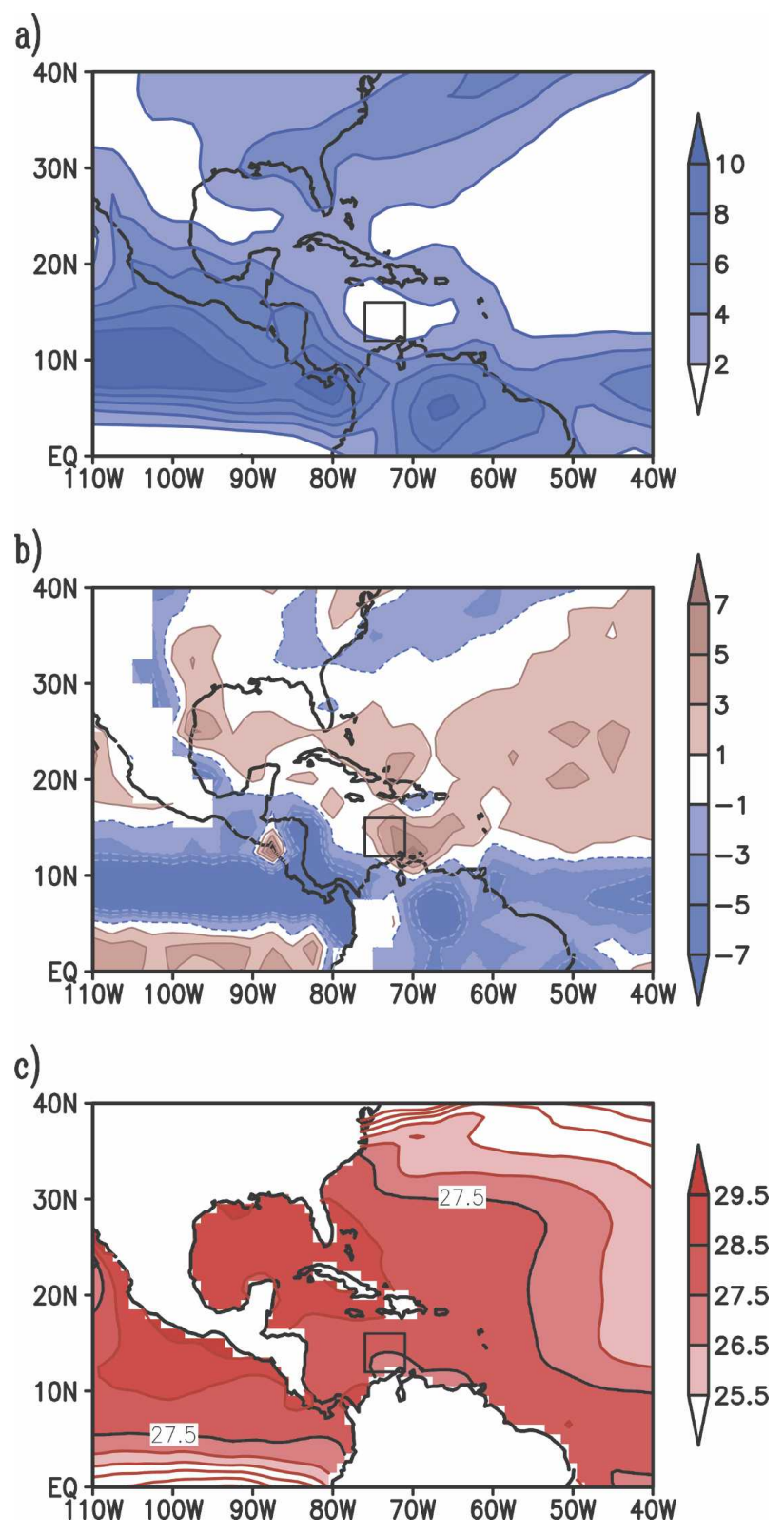

FIG. 9. July (a) precipitation $\left(\mathrm{mm} \mathrm{day}^{-1}\right)$, (b) vertical pressure velocity at $850 \mathrm{hPa}\left(\mathrm{Pa} \mathrm{s}^{-1} \times 100\right)$, and (c) sea surface temperature $\left({ }^{\circ} \mathrm{C}\right)$. The rectangle delineates the area from $12^{\circ}$ to $16^{\circ} \mathrm{N}$ and from $71^{\circ}$ to $76^{\circ} \mathrm{W}$.

Mexico, and north of the Greater Antilles (not presented). On the other hand, there is moisture flux convergence (MFC) over adjacent land areas. A region of strong MFD in the Caribbean Sea is between $70^{\circ}$ and $74^{\circ} \mathrm{W}$. In fact, over the Caribbean, the zonal moisture divergence dominates in the domain of the Caribbean LLJ. Between $11^{\circ}$ and $18^{\circ} \mathrm{N}$ (i.e., between the southern and northern boundaries of the Caribbean Sea), the MFD below the 700-hPa level extends from the Lesser 
a)

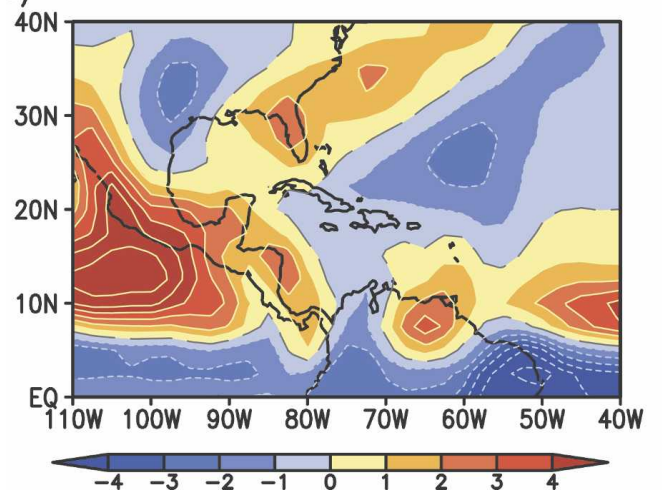

b)

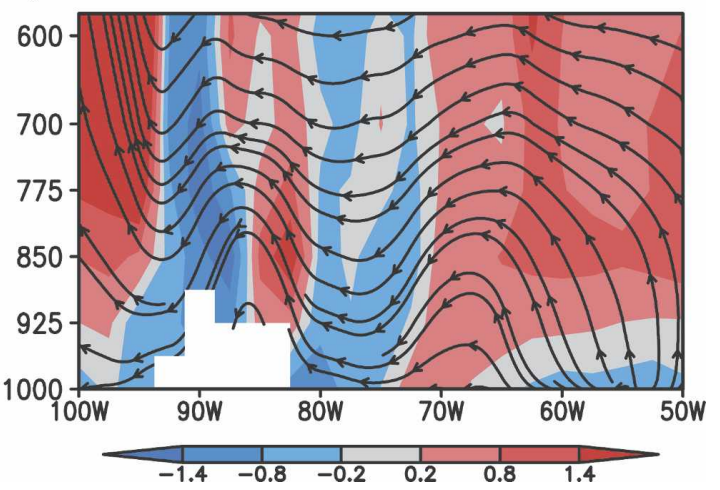

FIG. 10. (a) July-May difference of precipitation $\left(\mathrm{mm} \mathrm{day}^{-1}\right)$ from GPCP. Contour interval is $1 \mathrm{~mm} \mathrm{day}^{-1}$. (b) Pressure-longitude cross section of the July-May difference of diabatic heating $\left(\mathrm{K} \mathrm{s}^{-1} \times 10^{5}\right.$, shades) and the zonal and vertical wind (streamlines) averaged from $12^{\circ}$ to $16^{\circ} \mathrm{N}$ from ERA-40. In (b) the mountains of Central America are in white between $85^{\circ}$ and $90^{\circ} \mathrm{W}$.

Antilles (at about $61^{\circ} \mathrm{W}$ ) to $79^{\circ} \mathrm{W}$. Out of this region of MFD, the zonal divergence dominates over the opposing meridional convergence from $66^{\circ}$ to $74^{\circ} \mathrm{W}$, which is a region that also corresponds to the Caribbean LLJ. This indicates that the zonal divergence (and the easterly spatial intensification) is the main contributor to the total MFD in the region of the Caribbean LLJ. The strengthening of the Caribbean easterlies as an LLJ is directly related to stronger MFD.

The Caribbean minimum of precipitation is not only a spatial feature but also a temporal feature. Although the precipitation over the Caribbean is scarce yearround (in comparison to the ITCZ), the Caribbean precipitation (from GPCP) between $70^{\circ}$ and $75^{\circ} \mathrm{W}$ decreases from May to July (Fig. 10a) as the Caribbean LLJ intensifies, and then increases from July to August (not presented) as the Caribbean LLJ weakens. Additionally, from May to July there is stronger diabatic cooling and stronger subsidence over the Caribbean Sea (Fig. 10b). Figure 10b shows the diabatic heating and wind change from May to July. The diabatic heating was calculated as the residual from the thermodynamic equation using ERA-40 data. The subsidence over the Caribbean Sea is related to the MFD, the suppression of precipitation, and the diabatic cooling by entraining cooler and drier air from above into the lower levels of the Caribbean atmosphere.

On the other hand, over the eastern slope of Central America there is a combination of ascending motion, diabatic heating, and moisture flux convergence reflected as a strong precipitation rate. Between $81^{\circ}$ and $85^{\circ} \mathrm{W}$, over the Caribbean side of the Central American cordillera, the precipitation has increased more than $2 \mathrm{~mm} \mathrm{day}{ }^{-1}$ from May to July (Fig. 10a). As the easterlies encounter the Central American landmass and deflect upward, enhancements of convergence and convection occur, leading to more precipitation and more diabatic heating (Fig. 10). The diabatic heating increases more than $2 \times 10^{-5} \mathrm{~K} \mathrm{~s}^{-1}$ between 775 and 925 hPa (Fig. 10b), contrasting with the diabatic cooling over the central Caribbean. The intensification of the Caribbean east-west gradient of diabatic heating coincides with a monsoon-like summer strengthening of the easterly wind. In fact, the $925-\mathrm{hPa}$ zonal component of the divergent (irrotational) wind over the western Caribbean has become more easterly from May to June (as discussed above).

The strengthening (or onset) of the Caribbean LLJ from May to July may induce a direct circulation that influences the western Central America (northeastern tropical Pacific) midsummer drought (MSD). The western Central America MSD occurs from June to July (Magaña et al. 1999), lagging the Caribbean MSD. Over $90^{\circ} \mathrm{W}$, the western side of Central America shows a decrease in diabatic heating of $\sim 1.4 \times 10^{-5} \mathrm{~K} \mathrm{~s}^{-1}$ and greater descending motion. Essentially, as the Caribbean LLJ intensifies from May to June and then to July, the easterlies reach the Central American mountains and the monsoon heating. The easterlies deflect upward and subside over the western side of Central America (Fig. 10b). The subsidence most likely inhibits precipitation, resulting in less diabatic heating. This confirms the findings of Magaña and Caetano (2005). To the west of the MSD region the continuing intensification of the ITCZ is observed (at about $100^{\circ} \mathrm{W}$ ) with positive heating change and greater upward motion.

Throughout the year the precipitation in the Caribbean region is anticorrelated with the easterly Caribbean low-level wind. Figure 11 presents the correlation between the seasonal cycle of the Caribbean $925-\mathrm{hPa}$ 


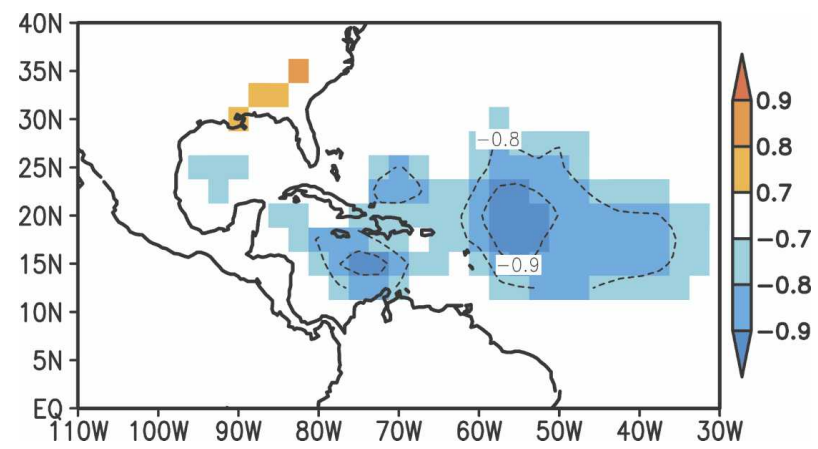

FIG. 11. Correlation between the 12-month seasonal cycle of precipitation and the 12-month seasonal cycle of Caribbean 925-hPa zonal wind index. The precipitation is from GPCP. The Caribbean $925-\mathrm{hPa}$ zonal wind index (multiplied by -1 ) is the area average between $12^{\circ}$ and $16^{\circ} \mathrm{N}$ and between $71^{\circ}$ and $76^{\circ} \mathrm{W}$ from NARR. Correlation coefficients significant at the $95 \%$ level are shown.

zonal wind (averaged from $12^{\circ}$ to $16^{\circ} \mathrm{N}$ and from $71^{\circ}$ to $76^{\circ} \mathrm{W}$ ) and the seasonal cycle of precipitation. It is observed that with an intensification of the easterly wind there is a weakening of precipitation over the Caribbean Sea centralized in the region of maximum easterlies, the Caribbean LLJ. Two other areas of strong anticorrelation are the subtropical North Atlantic and the Gulf of Mexico. The precipitation in the SNA (centered at $20^{\circ} \mathrm{N}, 55^{\circ} \mathrm{W}$ ) is anticorrelated with the stronger easterly wind that extends from that region. In contrast, the precipitation in the southeastern United States is positively correlated with a stronger flow from the Caribbean that extends to the Gulf of Mexico, providing moisture to the southeastern United States.

\section{c. Summer interannual variability of the Caribbean $L L J$}

The interannual variability of the Caribbean LLJ is analyzed for boreal summer months. The standard deviation of the monthly anomalies of the zonal component of the wind is computed as a measure of interannual variability. The anomalies are calculated from the 1979-2001 climatology. For the months of June through September the standard deviation is greater at $925 \mathrm{hPa}$ and roughly is bounded in the area of $12^{\circ}-16^{\circ} \mathrm{N}$ and $70^{\circ}-80^{\circ} \mathrm{W}$ (Fig. 12). The variability of the Caribbean LLJ is then summarized as an index of the anomalies of the 925-hPa zonal component of the wind averaged over the region of $12^{\circ}-16^{\circ} \mathrm{N}$ and $70^{\circ}-80^{\circ} \mathrm{W}$ (as in $\mathrm{Mu}-$ noz et al. 2006).

The autocorrelation of the Caribbean LLJ anomaly index in July with those of previous and subsequent months is calculated to determine the persistence of Caribbean LLJ anomalies. Table 1 presents the corre-

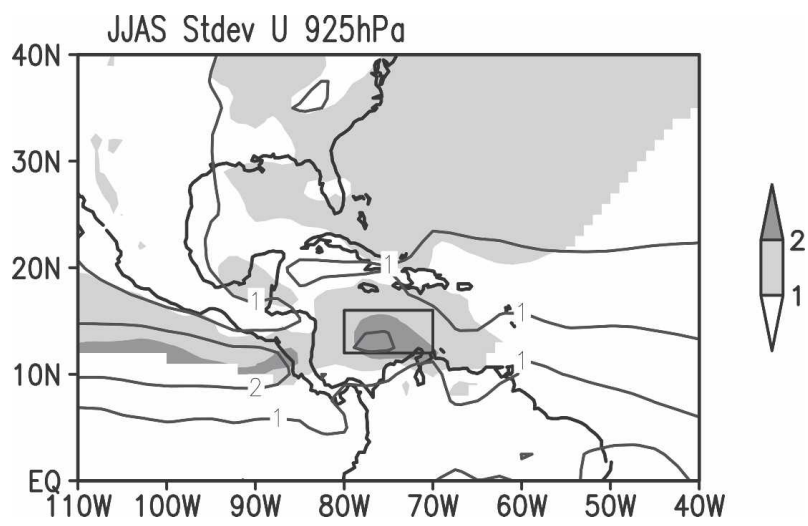

FIG. 12. June-September average std dev of the 925-hPa zonal wind anomalies $\left(\mathrm{m} \mathrm{s}^{-1}\right)$ from NARR (shades) and ERA-40 (contours).

lation between the Caribbean LLJ anomaly index in July and that from May through October separately, from NARR and ERA-40. From the results, the autocorrelation of the July Caribbean LLJ anomalies is significant at the $95 \%$ (99\%) level from June throughout September (from July throughout September), indicating persistence of July Caribbean LLJ monthly anomalies throughout September. Given this persistence, a determination of what processes in June lead to anomalies of the Caribbean LLJ in July may help with prediction of August-September Caribbean LLJ anomalies.

Regression analyses are performed to analyze the structure of the interannual variability of the Caribbean LLJ during summer. This approach was also used by Munoz et al. (2006) with a focus on the monthly anomalies of late summer (i.e., August and September). The focus in this discussion is on July and August anomalies and what June conditions lead July Caribbean LLJ anomalies. The months of July and August are chosen because these two months show a significant correlation of Caribbean LLJ anomalies and because within this period the midsummer drought occurs. Also, it is in July when the Caribbean LLJ is at its peak. The regressions are shown with respect to a unit increase in east-

TABLE 1. Correlation between Caribbean LLJ anomaly index in July and itself in other summer months.

\begin{tabular}{lcc}
\hline & NARR & ERA-40 \\
\hline May & 0.08 & -0.02 \\
Jun & 0.47 & 0.48 \\
Jul & 1.00 & 1.00 \\
Aug & 0.71 & 0.73 \\
Sep & 0.67 & 0.80 \\
Oct & 0.37 & 0.33 \\
\hline
\end{tabular}




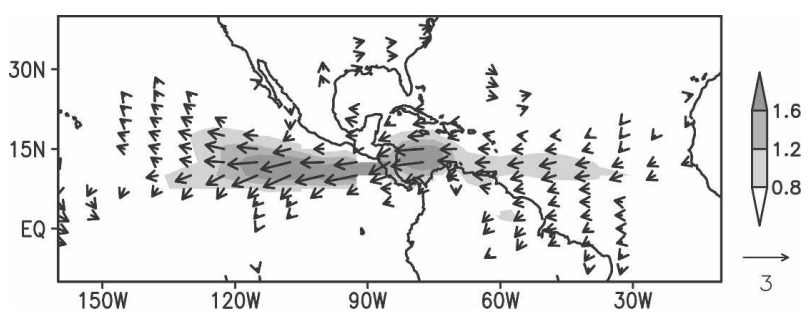

FIG. 13. July-August $925-\mathrm{hPa}$ wind anomaly vector $\left(\mathrm{m} \mathrm{s}^{-1}\right)$ regressed onto the Caribbean LLJ July-August anomaly index (i.e., $925-\mathrm{hPa}$ zonal wind averaged over $12^{\circ}-16^{\circ} \mathrm{N}$ and $70^{\circ}-80^{\circ} \mathrm{W}$ ). Values statistically significant at the $95 \%$ level are shown.

erly wind; hence, the discussion is based on a strengthening of the Caribbean LLJ.

As observed from Fig. 13, in July-August an intensification of the Caribbean LLJ is observed as part of an intensification of the flow from the tropical North Atlantic (east of the Caribbean Sea) crossing the Caribbean and Central America and extending to the northeastern tropical Pacific. There is an intensification of the flow into the Gulf of Mexico and the Gulf States of the United States that connects to the southeast United States. The changes in the wind in the Caribbean region correspond to an increase in the meridional SLP gradient across the Caribbean region and a cooling of the Caribbean SSTs.

Figure 14a shows the linear regression coefficients resulting from July-August SLP anomalies regressed on the Caribbean LLJ anomaly index. Over the IntraAmericas Sea (IAS; the Caribbean Sea and Gulf of Mexico regions) the surface pressure has intensified, especially over the Florida peninsula. The SLP anomalous pattern shows a meridional gradient from south to north across Central America and the Caribbean Sea. This intensification of the meridional SLP gradient in July-August is part of a greater anomalous pattern with increasing pressure over the tropical Atlantic between $30^{\circ} \mathrm{N}$ and $15^{\circ} \mathrm{S}$ and decreasing pressure over the tropical Pacific. Over the tropical Atlantic the changes in pressure are greater in the subtropical North Atlantic between $10^{\circ}$ and $30^{\circ} \mathrm{N}$. Over the Pacific the changes in pressure are negative from the western South American boundary to the west and are greater over the Niño-3.4 region. Hence, because of the slanted northwest-to-southeast orientation of the Central America isthmus, with negative pressure anomalies south of Central America and positive pressure anomalies over the IAS, the meridional pressure gradient across Central America and the Caribbean regions is further intensified, as well as the Caribbean LLJ.

Similarly, there is an interbasin SST anomaly (SSTA) pattern associated with changes in the intensity of the
July-August Caribbean LLJ. The July-August SSTAs regressed onto the July-August Caribbean LLJ anomaly index shows positive SSTAs in the tropical Pacific and negative SSTAs in the tropical Atlantic (Fig. 14b). The positive SSTAs in the Pacific are strongest in the equatorial Pacific Niño-3 and Niño-3.4 regions. The negative anomalies in the tropical Atlantic are strong in the equatorial region and in the tropical North Atlantic, in particular in the Caribbean Sea region. In the Caribbean Sea, the negative SSTAs are greater closer to the northern coast of South America. These Caribbean SSTAs are in consonance with greater upwelling throughout the northern coast of South America and stronger thermodynamic cooling as the wind intensifies and greater evaporation occurs.

In the Pacific the changes are those of a warm ENSO event with a decrease in SLP and an increase in SST. Amador et al. (2000) also observed the low-level jet over the Caribbean to strengthen during tropical Pacific El Niño events. Additionally, the interbasin pattern of SST and SLP associated with the Caribbean LLJ is similar to the one observed by Giannini et al. (2000), which is associated with less precipitation over the Caribbean and Central America region in July-August, suggesting that the Caribbean LLJ may modulate the precipitation anomalies in the Caribbean basin. Nonetheless, significant anticorrelation between the Niño-3.4 SSTAs and July-August Caribbean LLJ anomalies is observed from spring throughout summer. This negative correlation is in contrast with the positive lagged correlation between the tropical North Atlantic in boreal spring and the boreal winter tropical Pacific anomalies (Enfield and Mayer 1997).

By quantifying the relation between the July Caribbean LLJ anomaly index and anomalous conditions in June, we try to determine the precedent anomalies that lead to changes in the Caribbean LLJ intensity. The regression coefficients of the July Caribbean LLJ index regressed onto the June anomalies of SLP and SST are shown in Figs. 14c-d. The Caribbean Sea does not show significant SSTAs. The stronger SSTAs closer to the Caribbean Sea are in the equatorial Pacific, in particular in the Niño-3 region. Also, the SLP shows strong negative anomalies over the tropical Pacific but no significant anomalies over the Gulf of Mexico, indicating that the subsequent July-August positive SLP anomalies in the IAS region are a response to the remote forcing from the tropical Pacific and the eastern tropical North Atlantic in June. In effect, the changes in the Pacific are related to the IAS region by modifying the meridional and the zonal atmospheric circulations that link the IAS with the tropical Pacific. As greater upris- 

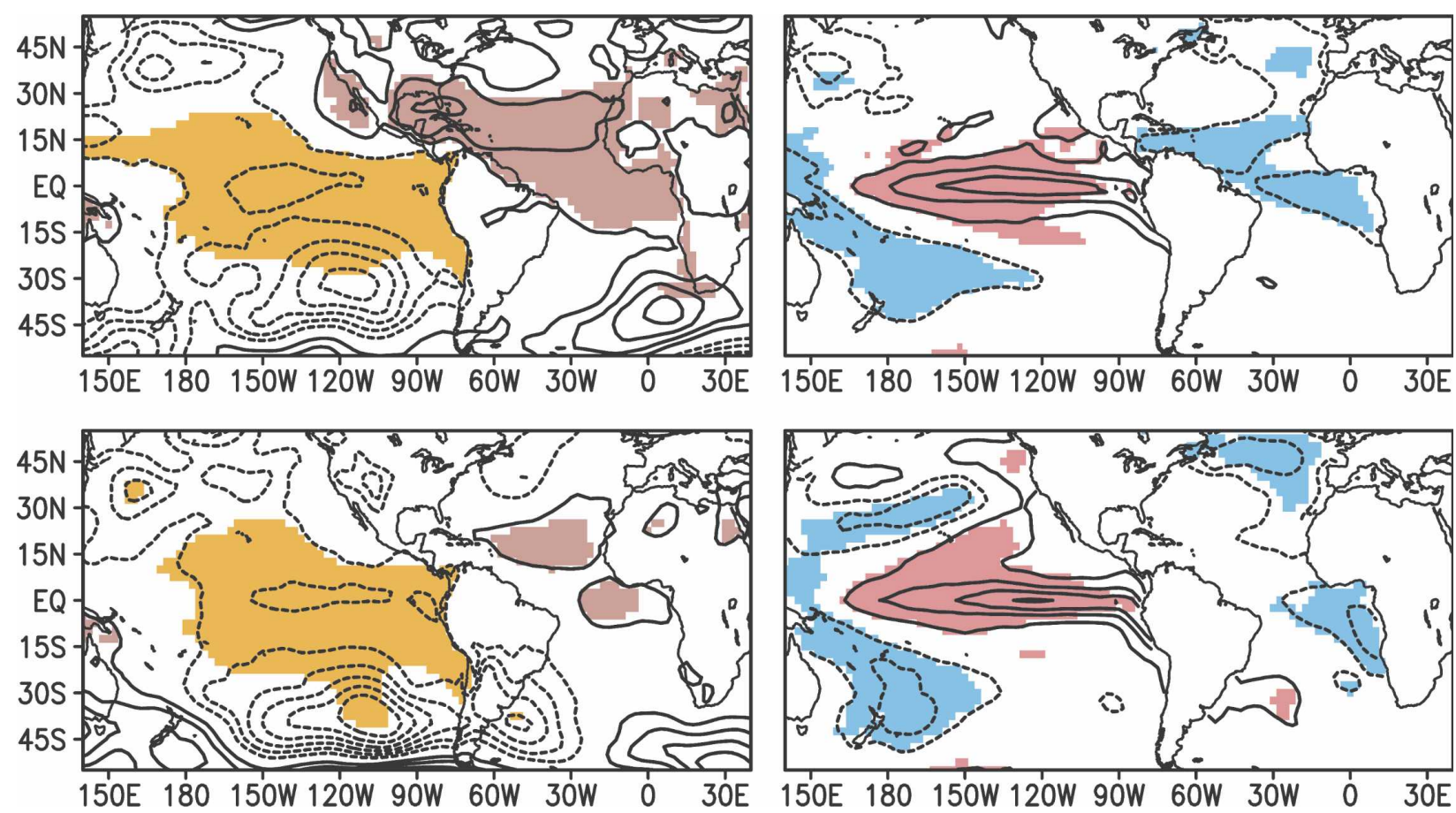

FIG. 14. Regression of the ERA-40 Caribbean LLJ anomaly index onto (left) ERA-40 SLP anomalies and (right) ERSST SST anomalies. Dashed contours indicate negative values and solid contours indicate positive values. Contour interval for SLP regression plots is $0.25 \mathrm{hPa}$ starting at $\pm 0.25 \mathrm{hPa}$. Contour interval for SST regression plots is $0.20^{\circ} \mathrm{C}$ starting at $\pm 0.15^{\circ} \mathrm{C}$. (top) Regression of July-August SLP and SST anomalies onto Caribbean LLJ July-August anomaly index. (bottom) Regression of June SLP and SST anomalies onto Caribbean LLJ July anomaly index. Values statistically significant at the $95 \%$ level are shaded.

ing motion occurs in the tropical Pacific, weaker uprising motion occurs in the IAS (in particular, stronger low-level sinking over the Gulf of Mexico region). This sinking over the IAS increases the surface pressure north of the Caribbean region and intensifies the lowlevel easterlies. As the low-level easterlies intensify in July, greater upwelling and greater thermodynamic cooling decrease the SSTs in the Caribbean. The negative SSTs further contribute to the increase of the SLP anomalies. Over the Pacific, the SSTs are warm and the SLP stays lower than the climatology. The meridional pressure gradient across Central America and the Caribbean further intensifies the Caribbean LLJ.

\section{Summary and conclusions}

This study has analyzed the low-level jet over the Caribbean region and the potential mechanisms that control it. The characterization has been done mostly from the NARR with high spatial and temporal resolutions. The Caribbean LLJ is an extension of the anticyclone of the subtropical North Atlantic (the Bermuda high), and its northeasterly Atlantic trades are amplified by temperature and orographic influences in the Caribbean region. The Caribbean low-level wind has peaks in February and July and has minima in May and October, presenting a semiannual cycle that is in phase with the semiannual cycle of the northward gradient of pressure across the Caribbean Sea. The diurnal variability of the Caribbean LLJ in February and July has a semidiurnal cycle with a nighttime maximum 1.2 times the afternoon minimum. The Caribbean LLJ's peaks in July and February have a similar vertical structure to that of other LLJs, with a relative minimum close to the surface, a maximum at about $925 \mathrm{hPa}$, and decreasing winds with height. The core of the Caribbean LLJ lies at $925 \mathrm{hPa}$ between $12^{\circ}-16^{\circ} \mathrm{N}$ and $71^{\circ}-$ $76^{\circ} \mathrm{W}$. Comparing the diurnal, seasonal, and interannual variability of the Caribbean LLJ, the seasonal variability is the one that dominates.

In addition to the stronger northward gradients of pressure in February and July there are regional thermal gradients that intensify the wind. From the central Caribbean to the south there is a southward air temperature gradient, which may be a combination of the influence of the mountains (land) heating to the south and cooling associated with a minimum of precipitation over the central Caribbean. The southward temperature gradient (orthogonal to the main flow) provides a 
baroclinic structure to which the easterly wind would intensify. The friction closer to the surface most likely weakens the winds at the lower levels, exhibiting then a maximum away from the surface (at $925 \mathrm{hPa}$ ). Modeling experiments with and without the surrounding mountains and landmasses would be needed to validate these hypotheses. Modeling experiments may also help to clarify whether the Caribbean LLJ is a reflecting wave resulting from the blocking of the winds by the Central American cordillera.

The moisture flux across the central Caribbean also has a jet structure in February and July. Downwind of the maximum winds of the Caribbean LLJ, the bifurcation of the moisture flux indicates more moisture flux to the north in July than in February. It is throughout the warm season, from May to September, that the moisture flux from the Caribbean region into the Gulf of Mexico is strongest.

The strengthening of the winds over the Caribbean Sea from May to July is influenced by the changes associated with the northward displacement of the ITCZ and the evolution of the rainy season in Central America. In combination with the northward shift of the ITCZ from May to July, a region of upper-level $(250 \mathrm{hPa})$ convergence and stronger descent over the Sargasso Sea is collocated with a region of stronger rotational wind and lower-level divergence over the tropical North Atlantic and Caribbean Sea. Over the central Caribbean a spatial minimum in precipitation is correspondent to subsidence, moisture flux divergence, and diabatic cooling over the Caribbean Sea. Also, the establishment of an east-west gradient of diabatic heating between Central America and the Caribbean (as the Caribbean midsummer drought evolves) is related with a stronger easterly irrotational wind that results in a strengthening of the Caribbean LLJ. The intensification of the Caribbean LLJ from May to June and the stronger subsidence over the leeward (western) side of Central America influence the onset of the midsummer drought over western Central America.

On interannual time scales, the Caribbean LLJ intensification is associated with an increase in the Caribbean meridional gradient of SLP as the tropical Pacific warms and the tropical Atlantic cools, altering the meridional and zonal circulations that reach the IntraAmericas Sea region.

In summary, the Caribbean LLJ is an intrinsic component of the Caribbean climate. Through this study a greater understanding of another LLJ of the Americas, the Caribbean LLJ, has been achieved.

Acknowledgments. The quantification of the diabatic heating was done and provided by Steven Chan at the
Department of Atmospheric and Oceanic Science of the University of Maryland at College Park. Also, comments from reviewer B and the editor are appreciated. Sumant Nigam and Alfredo Ruiz-Barradas wish to acknowledge the support of Grants NOAA/CPPA NA17 EC1483 and NSF ATM-0649666.

\section{REFERENCES}

Adler, R. F., and Coauthors, 2003: The version-2 Global Precipitation Climatology Project (GPCP) monthly precipitation analysis (1979-present). J. Hydrometeor., 4, 1147-1167.

Amador, J. A., V. O. Magaña, and J. B. Pérez, 2000: The low level jet and convective activity in the Caribbean. Proc. 24th Conf. on Hurricanes and Tropical Meteorology, Ft. Lauderdale, FL, Amer. Meteor. Soc., 114-115.

Berbery, E. H., and E. A. Collini, 2000: Springtime precipitation and water vapor flux over southeastern South America. Mon. Wea. Rev., 128, 1328-1346.

— basin in South America. J. Hydrometeor., 3, 630-645.

_, E. M. Rasmusson, and K. E. Mitchell, 1996: Studies of North American continental-scale hydrology using Eta model forecast products. J. Geophys. Res., 101, 7305-7320.

Blackadar, A. K., 1957: Boundary layer wind maxima and their significance for the growth of nocturnal inversions. Bull. Amer. Meteor. Soc., 38, 283-290.

Bonner, W. D., and J. Paegle, 1970: Diurnal variations in boundary layer winds over the south-central United States in summer. Mon. Wea. Rev., 98, 735-744.

Bosilovich, M. G., and S. D. Schubert, 2002: Water vapor tracers as diagnostics of the regional hydrologic cycle. J. Hydrometeor., 3, 149-165.

Chen, P., M. P. Hoerling, and R. M. Dole, 2001: The origin of the subtropical anticyclones. J. Atmos. Sci., 58, 1827-1835.

Enfield, D. B., and D. A. Mayer, 1997: Tropical Atlantic sea surface temperature variability and its relation to El NiñoSouthern Oscillation. J. Geophys. Res., 102, 929-946.

Giannini, A., Y. Kushnir, and M. A. Cane, 2000: Interannual variability of Caribbean rainfall, ENSO, and the Atlantic Ocean. J. Climate, 13, 297-311.

Gill, A. E., 1980: Some simple solutions for heat-induced tropical circulation. Quart. J. Roy. Meteor. Soc., 106, 447-462.

Graham, N. E., and T. P. Barnett, 1987: Sea surface temperature, surface wind divergence, and convection over tropical oceans. Science, 238, 657-659.

Helfand, H. M., and S. D. Schubert, 1995: Climatology of the simulated Great Plains low-level jet and its contribution to the continental moisture budget of the United States. J. Climate, 8, 784-806.

Holton, J. R., 1967: The diurnal boundary layer wind oscillation above sloping terrain. Tellus, 19, 199-205.

_ 1992: Elementary applications of the basic equations. An Introduction to Dynamic Meteorology. 3rd ed. Academic Press, 58-85.

Inoue, M., I. C. Handoh, and G. R. Bigg, 2002: Bimodal distribution of tropical cyclogenesis in the Caribbean: Characteristics and environmental factors. J. Climate, 15, 2897-2905.

Kalnay, E., and Coauthors, 1996: The NCEP/NCAR 40-Year Reanalysis Project. Bull. Amer. Meteor. Soc., 77, 437-471.

Magaña, V., and E. Caetano, 2005: Temporal evolution of sum- 
mer convective activity over the Americas warm pools. Geophys. Res. Lett., 32, L02803, doi:10.1029/2004GL021033.

—_ J. A. Amador, and S. Medina, 1999: The midsummer drought over Mexico and Central America. J. Climate, 12, 1577-1588.

Mesinger, F., and Coauthors, 2006: North American Regional Reanalysis. Bull. Amer. Meteor. Soc., 87, 343-360.

Mo, K. C., M. Chelliah, M. L. Carrera, R. W. Higgins, and W. Ebisuzaki, 2005: Atmospheric moisture transport over the United States and Mexico as evaluated in the NCEP regional reanalysis. J. Hydrometeor., 6, 710-728.

Munoz, E., A. Ruiz-Barradas, S. Nigam, and A. J. Busalacchi, 2006: Variability of the Caribbean low-level jet and its related climate anomalies. Eos, Trans. Amer. Geophys. Union, 87 (Joint Assembly Suppl.), Abstract A33C-04.

Rasmusson, E. M., 1967: Atmospheric water vapor transport and the water balance of North America: Part I. Characteristics of the water vapor flux field. Mon. Wea. Rev., 95, 403-426.

Reynolds, R. W., N. A. Rayner, T. M. Smith, D. C. Stokes, and W. Wang, 2002: An improved in situ and satellite SST analysis for climate. J. Climate, 15, 1609-1625.

Rodwell, M. J., and B. J. Hoskins, 2001: Subtropical anticyclones and summer monsoons. J. Climate, 14, 3192-3211.
Seager, R., R. Murtugudde, N. Naik, A. Clement, N. Gordon, and J. Miller, 2003: Air-sea interaction and the seasonal cycle of the subtropical anticyclones. J. Climate, 16, 1948-1966.

Smith, T. M., and R. W. Reynolds, 2004: Improved extended reconstruction of SST (1854-1997). J. Climate, 17, 2466-2477.

Stensrud, D. J., 1996: Importance of low-level jets to climate: A review. J. Climate, 9, 1698-1711.

Taylor, M. A., D. B. Enfield, and A. A. Chen, 2002: Influence of the tropical Atlantic versus the tropical Pacific on Caribbean rainfall. J. Geophys. Res., 107, 3127, doi:10.1029/2001JC001097.

Ting, M. F., and H. L. Wang, 2006: The role of the North American topography on the maintenance of the Great Plains summer low-level jet. J. Atmos. Sci., 63, 1056-1068.

Uppala, S. M., and Coauthors, 2005: The ERA-40 re-analysis. Quart. J. Roy. Meteor. Soc., 131, 2961-3012.

Vera, C., and Coauthors, 2006: The South American Low-Level Jet Experiment. Bull. Amer. Meteor. Soc., 87, 63-77.

Xie, S.-P., H. Xu, W. S. Kessler, and M. Nonaka, 2005: Air-sea interaction over the eastern Pacific warm pool: Gap winds, thermocline dome, and atmospheric convection. J. Climate, 18, 5-20. 